\title{
Review of Indo-Pacific coral reef fish systematics: 1980 to 2014
}

\author{
Gerald R. Allen
}

Received: 16 April 2014/Revised: 6 May 2014/ Accepted: 9 May 2014/Published online: 8 July 2014

(C) The Author(s) 2014. This article is published with open access at Springerlink.com

\begin{abstract}
Coral reef fish taxonomy from 1980 to 2014 is reviewed, providing a subjective analysis of new species descriptions, including statistics on the rate of new discoveries, which families and genera have attracted the most taxonomic interest, the main geographic areas for new discoveries, which journals the new taxa were published in, the nationality of authors, the most productive authors, and the main focal areas for reef fish field work.
\end{abstract}

Keywords Coral fish $\cdot$ Systematics $\cdot$ Review

\section{Introduction}

Eschmeyer et al. (2010) presented an excellent summary of the history of marine fish biodiversity studies, with particular emphasis on statistics pertaining to the number of new taxa described (species, genera, and families), number of authors involved, leading museums for type specimen deposition, and leading geographic regions for new species discoveries. The current paper provides further analysis restricted to Indo-Pacific coral reef fishes, providing a general overview that covers the past 35 years, approximately correlated with the period since the first IndoPacific Fish Conference was held in 1981. Despite a trend of budget restraints associated with traditional museumbased collecting expeditions, this era was exceedingly productive with many exciting finds throughout this vast region. The present work includes a subjective analysis of new species descriptions, providing statistics on the rate of

\section{G. R. Allen $(\bowtie)$}

Western Australian Museum, Locked Bag 49, Welshpool DC, Perth, Western Australia 6986, Australia

e-mail: tropical_reef@bigpond.com new discoveries, which families and genera have attracted the most taxonomic interest, the main geographic areas for the discoveries, where the new taxa were published, nationality of authors, the most productive authors, and the main focal areas for coral reef fish field work.

\section{Materials and methods}

The present analysis is restricted to coral reef fishes, which are herein defined as species that are entirely or mainly confined to coral reefs and intermingled substrata (sand/ rubble patches, seagrass beds, etc.), including deep reefs to about $100 \mathrm{~m}$ depth. Geographic coverage is limited to tropical and subtropical seas of the Indian and western Pacific Ocean with the eastern limit including the Hawaiian Islands and Easter Island.

An Excel database was constructed by extracting an overall checklist of species described since 1980 from the author's fish-mapping program. Essentially, this continually updated program consists of distribution maps for every known species of reef fish in the tropical Indo-Pacific from East Africa and the Red Sea to the islands of Oceania. Distribution polygons, bounded by the outermost records of occurrence, were drawn on standard equal-area base maps, initially utilizing ArcView GIS software (Esri, New York), but now employing Quantum GIS (http://www.qgis. org/). In addition to distribution maps the program includes an accompanying database with family, genus, and species names, as well as the author(s) and year of publication. The primary type locality for each species was added to the database, utilizing the Catalog of Fishes website (Eschmeyer 2014). Information pertaining to field work locations was gleaned from the literature, online museum records, and direct contact with several institutions (see 
acknowledgements). Institutional acronyms follow Sabaj Pérez (2010).

\section{New taxa: 1980-present}

The total number of new coral reef fishes described from 1 January 1980 to 31 March 2014 is 1,434 species belonging to 317 genera and 69 families. The graph in Fig. 1 shows the uneven nature of yearly totals. The overall average for the 34-year period from $1980-2013$ is 41.6 species per year. If we look at the average species per year for each decade there is a slight decrease during the 1990s (35.5) compared to the 1980s (38.1), but a strong increase in the new millennium with 47.5 in the 2000s and 51.3 from 2010 through the end of 2013. Gobiids, labrids, apogonids, and pomacentrids are the leading families for new species descriptions since 1980 (Table 1). Gobiidae, with an impressive total of 327 species, is the only family with more than 200 new taxa described. A significant second tier, boasting totals of 55-73 species includes blenniids, bythitids, pseudochromids, tripterygiids, and serranids. The top 25 families, which includes those with 10 or more new taxa, accounts for 1,311 species or approximately 91 percent of the total species described during this period. A total of 69 families contained new species.

Not surprisingly, two goby groups, Eviota and Trimma, are the leading genera with a combined total of 120 species described (Table 2). Other goby groups that feature in the list of leading genera with 10 or more species described include Priolepis (18), Vanderhorstia (18), Amblyeleotris (16), Bryaninops (13), and Pleurosicya (10). The apogonid genus Apogon (now split into Apogon, Apogonichthyoides, Jaydia, Nectamia, Ostorhinchus, Pristiapogon, Pristicon, Zapogon, and Zoramia) is second only to Eviota with 59 species described.

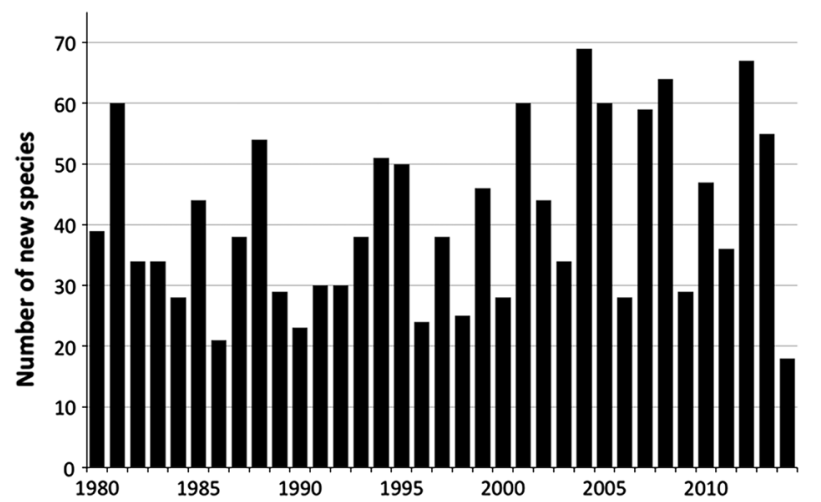

Fig. 1 Graph showing number of new coral reef fish species from January 1980 to April 2014
Table 1 Number of new species listed by family: 1980-2014

\begin{tabular}{|c|c|}
\hline Family & Species \\
\hline Gobiidae & 327 \\
\hline Labridae & 151 \\
\hline Apogonidae & 103 \\
\hline Pomacentridae & 102 \\
\hline Blenniidae & 73 \\
\hline Bythitidae & 71 \\
\hline Pseudochromidae & 69 \\
\hline Tripterygiidae & 62 \\
\hline Serranidae & 55 \\
\hline Syngnathidae & 38 \\
\hline Ptereleotridae & 28 \\
\hline Muraenidae & 26 \\
\hline Callionymidae & 25 \\
\hline Soleidae & 24 \\
\hline Opistognathidae & 20 \\
\hline Pinguipedidae & 20 \\
\hline Mullidae & 17 \\
\hline Plesiopidae & 17 \\
\hline Holocentridae & 15 \\
\hline Congridae & 14 \\
\hline Scorpaenidae & 14 \\
\hline Pomacanthidae & 11 \\
\hline Acanthuridae & 11 \\
\hline Scaridae & 10 \\
\hline Monacanthidae & 10 \\
\hline
\end{tabular}

Table 2 Number of new species listed by genera: 1980-2014

\begin{tabular}{llll}
\hline Genus & Species & Genus & Species \\
\hline Eviota & 63 & Hippocampus & 17 \\
Apogon & 59 & Opistognathus & 17 \\
Trimma & 57 & Amblyeleotris & 16 \\
Cirrhilabrus & 39 & Gymnothorax & 15 \\
Enneapterygius & 38 & Siphamia & 15 \\
Pseudochromis & 36 & Bryaninops & 13 \\
Chromis & 34 & Callionymus & 12 \\
Pomacentrus & 33 & Meiacanthus & 12 \\
Ecsenius & 26 & Paracheilinus & 12 \\
Aseraggodes & 25 & Chrysiptera & 11 \\
Pseudanthias & 24 & Parioglossus & 11 \\
Diancistrus & 24 & Ptereleotris & 11 \\
Helcogramma & 20 & Cirripectes & 10 \\
Parapercis & 20 & Coris & 10 \\
Halichoeres & 19 & Pleruosicya & 10 \\
Priolepis & 18 & Plesiops & 10 \\
Vanderhorstia & 18 & Synchiropus & 10 \\
\hline
\end{tabular}


Table 3 Number of new genera of coral reef fishes described from 1980 to 2014 according to family

\begin{tabular}{ll}
\hline Family & New genera \\
\hline Bythitidae & 13 \\
Gobiidae & 12 \\
Pseudochromidae & 8 \\
Xenisthmidae & 4 \\
Apogonidae & 3 \\
Plesiopidae & 2 \\
Platycephalidae & 2 \\
Blenniidae & 2 \\
\hline
\end{tabular}

A total of 70 new genera and two new families were described during the period covered by this study. Table 3 lists the families containing two or more new genera. Bythitids, gobiids, and pseudochromids were the leading groups for new generic descriptions, frequently due to splitting of existing genera.

Two monotypic coral reef-associated families were described during this period. Dentatherina merceri Patten and Ivantsoff 1983 was described as a new genus, species and subfamily (Dentatherinae) of atherinoid fish from coral reefs of the Molucca Islands, Indonesia. The subfamily was later elevated to family status by Parenti (1984) and also recognized as a valid family by Nelson (1994). Protoanguilla palau Johnson et al. 2012, an unusual eel collected from a cave at the Palau Islands, was also described as a new genus and new family (Protanguillidae) by the original species' authors.

\section{Geographic origin of new reef fish taxa}

Analysis of the geographic location of type localities for new reef fish taxa described between 1 January 1980 and 1 April 2014 reveals that the most number of species was described from the Coral Triangle, the world's richest area for coral reef fishes (Table 4). This region, which encompasses Indonesia, Philippines, Papua New Guinea, Solomon Islands, Timor-Leste, and Sabah Province of Malaysian Borneo, is home to 2,642 reef fishes (current data from author's mapping program) and encompasses the world's most diverse habitat conditions for reefinhabiting species (Allen 2008). An analysis (Allen and Erdmann 2012) of both GIS distributional data and in situ surveys indicates the very richest area is centred on the Halmahera-West Papuan region of Indonesia, which currently (till March 2014) boasts a total of at least 1,875 species. The Raja Ampat Islands, off the extreme western tip of the island of New Guinea, lies in the heart of this area and has a current total of slightly over 1,500 species of reef fish recorded from in situ surveys.
Table 4 Number of species described from 1980 to 2014 by major geographic regions

\begin{tabular}{ll}
\hline Major region & Species \\
\hline Coral Triangle & 340 \\
W Indian Ocean & 191 \\
Australia & 166 \\
Polynesia & 160 \\
NW Pacific & 142 \\
Arabian Peninsula & 140 \\
Melanesia & 86 \\
Micronesia & 80 \\
\hline
\end{tabular}

The western Indian Ocean was also a prime location for numerous taxonomic descriptions published during this period with 191 species (Table 4). The region includes the East African coast, numerous offshore island groups (most notably Madagascar, Comoros, Mascarene Islands, Socotra, Seychelles, Chagos, Laccadives, and Maldives), as well as Sri Lanka and the west coast of India. The total number of new species described is increased considerably (to 331) and nearly equal to the Coral Triangle if the Arabian Peninsula is added. However, for the purpose of this analysis the surrounding waters of the Arabian Peninsula, composed of the Red Sea, Persian Gulf, and coastal seas from Yemen to the United Arab Emirates, is considered as a separate region. Other major regions attracting significant taxonomic interest include Australia, the widely scattered islands of Polynesia (including Hawaii), and the northwest Pacific, which includes the subtropical seas of Taiwan, China, and Japan. The remaining locations listed in Table 3 include the Melanesian islands excluding New Guinea (Papua New Guinea and Indonesian Papua) and the Solomon Islands, which are included in the Coral Triangle total, and the islands of Micronesia.

In terms of more restricted subregions (generally countries, isolated seas, or island groups) Indonesia was the leading country for taxonomic focus with 177 species described (Table 5). This total excludes 41 species described from Papua and West Papua provinces, which for the purpose of this analysis are lumped with 74 species from Papua New Guinea to produce an overall total of 115 species for the island of New Guinea, which of course is a natural rather than political biogeographic unit. The second most productive region for new species was Japan, particularly the Ryukyu Islands and to a lesser extent the Ogasawara Islands. Of the remaining locations, the Marquesas Archipelago is notable for the high number of described taxa (35) considering its relatively small area compared to most of the other subregions. This is no doubt the result of its very high endemism (about $7 \%$; Allen 2008) in combination with several recent large-scale collecting expeditions where ichthyocides were employed. Similarly, the relatively high total for New Caledonia is no 
Table 5 Number of species described from 1980 to 2014 by leading geographic subregions

\begin{tabular}{lc}
\hline Subregion & Species \\
\hline Indonesia & 178 \\
Japan & 116 \\
New Guinea & 116 \\
Philippines & 90 \\
Red Sea & 86 \\
Fiji-Tonga & 63 \\
Mascarene Islands & 46 \\
Marquesas & 35 \\
New Caledonia & 34 \\
Oman & 30 \\
\hline
\end{tabular}

doubt a direct result of a major French scientific presence, in the form of ORSTOM (now replaced by IRD), on the island for many decades. A final restricted locality worth mentioning is Oman, from which numerous new taxa were described by John Randall and associates in connection with the production of Coastal Fishes of Oman (Randall 1995).

\section{Publications}

Reef fish taxonomists have never had such a wide variety of publication options. The advent of electronic publishing has certainly fostered a new era for publishing new species descriptions. Descriptions were published in 106 different journals during the 34-year period of the current study. A list of the most popular publishing venues appears in Table 6 . The list is headed by Aqua, International Journal of Ichthyology, a privately owned journal launched in 1994 and published in Pavia, Italy. Much of its appeal is due to a relatively short waiting period and no restrictions or charges for use of colour illustrations. The second most popular outlet is Zootaxa, an online/print journal that began in 2001. Numerous freshwater and marine fish descriptions have been published in this journal, which caters to all branches of zoology. Its popularity is partly due to a rapid turn-around, free colour use, and easy on line access for broad dissemination. The third most popular venue with slightly more than 100 new species descriptions is Indo-Pacific Fishes, a publication of the Bishop Museum, Honolulu, Hawaii, edited by renowned ichthyologist John E. Randall (see below). The journal specializes in family and generic reviews and is published at irregular intervals, with 40 issues published from November 1982 to July 2011. Number four on the list is Revue française d'Aquariologie Herpétologie, which was published from 1979 to 1999 by the Museum of Zoology of the University of Henri Poincaré at Nancy, France. Its popularity was largely due to a liberal use of color illustrations and excellent editorship of the late Professor Bruno
Table 6 Leading journals for new coral reef fish descriptions: 1980-2014

\begin{tabular}{ll}
\hline Journal & New species \\
\hline Aqua, International Journal of Ichthyology & 160 \\
Zootaxa & 117 \\
Indo-Pacific Fishes & 101 \\
Revue française d'Aquariologie Herpétologie & 99 \\
The Beagle (No. Territory Museum Arts and Sci.) & 82 \\
Records of the Australian Museum & 45 \\
Bull. National Mus. of Nature and Science (Japan) & 40 \\
Japanese Journal of Ichthyology & 39 \\
Copeia & 38 \\
Proceedings Biological Society of Washington & 36 \\
Theses Zoologicae & 35 \\
Smithsonian Contributions to Zoology & 33 \\
Pacific Science & 33 \\
Proceedings California Academy of Science & 32 \\
Smithiana & 31 \\
Ichthyological Research & 32 \\
Canadian Journal of Zoology & 30 \\
Cybium & 27 \\
Records of the Western Australian Museum & 23 \\
Raffles Bulletin of Zoology & 23 \\
Bulletin of Marine Science & 22 \\
Zoological Studies & 22 \\
Israel Journal of Zoology & 19 \\
Journal of Ocean Science & 18 \\
Ichthyological Bulletin & 17 \\
Memoirs of Museum Victoria (Australia) & \\
J.L.B. Smith Inst. of Ichthyology Special Publ. & 15 \\
\hline & \\
&
\end{tabular}

Condé. The impressive number of species published in the Beagle (Records of the Museums and Art Galleries of the Northern Territory Museum, Darwin, Australia) is largely attributable to voluminous reviews of bythitid fishes by $\mathrm{P}$. R. Møller, J. G. Nielsen and W. Schwarzhans from 2005-2011. Japanese ichthyology is well represented in the list of leading journals with a combined total of 71 new reef fish descriptions for the Japanese Journal of Ichthyology and its entirely English-language successor, Ichthyological Research. Numerous new species descriptions, particularly of gobiid fishes have also appeared in recent years in the Bulletin of the National Museum of Nature and Science. Leading outlets for new reef fish descriptions in the Southern Hemisphere include the Records of the Australian Museum and various publications of the South African Institute of Aquatic Biodiversity (formerly J.L.B. Smith Institute of Ichthyology) including Smithiana, Ichthyological Bulletin, and the J.L.B. Smith Institute of Ichthyology 
Special Publications. In addition to journal publications, descriptions of 46 species were published in various books including Allen (1991), Allen et al. (2007), Allen and Erdmann (2012), Cornic (1987), and Randall (1995).

\section{Authorship}

The present analysis from 1980 to 2014 reveals that 1,434 reef fish descriptions were published by 278 different authors based in 26 countries (Table 7). The five leading countries include the United States of America, Japan, Australia, France, and the United Kingdom. The total (170) authors for the leading three countries account for $62 \%$ of all species descriptions. This no doubt reflects the level of funding for coral reef endeavours as well as proximity to field work areas, and the number of institutions that have staff engaged in systematics of reef fishes.

The most productive authors in terms of the number of new species described are shown in Table 8. This table features authors with more than 30 species described during the analysis period.

\section{John E. Randall, a living legend}

The present analysis confirms what is common knowledge among coral reef ichthyologists - that John E. Randall (Fig. 2), former Curator of Fishes at the Bishop Museum, Honolulu, Hawaii, is a veritable living legend. His publishing output over the years has been absolutely phenomenal and begs the question among us mere mortals of how does he find the time and energy for the amazing number of new taxa he continually describes. "Jack" as he is known to his many friends, colleagues and students, began his publishing career in 1952 when he co-authored his first paper dealing with a marine biological study of Onotoa Atoll, Gilbert Islands that appeared in the Atoll Research Bulletin (Banner and Randall 1952). His first new species descriptions appeared soon after, involving five species of the acanthurid genus Ctenochaetus (see Randall 1955). Now, almost 59 years later and approaching the grand milestone of 90 years of age in May 2014, he is still going strong. Although it is almost impossible to keep track of his publication record, totals kindly supplied by his wife Helen indicate he now (to March 2014) has 862 publications to his credit, including 14 voluminous guidebooks on fishes. Eschmeyer et al. (2010) acknowledged Randall as the eighth most productive author of all time for marine fish descriptions with a total of 705 species (and 51 additional species since 2009). During the period covered by the present study he has published descriptions of 497 coral
Table 7 Number of authors of coral reef fish descriptions according to country (almost always, but not necessarily indicative of author nationality): 1980-2014

\begin{tabular}{llll}
\hline Country & No. authors & Country & No. authors \\
\hline USA & 84 & China & 3 \\
Japan & 55 & Chile & 2 \\
Australia & 31 & Denmark & 2 \\
France & 15 & Saudi Arabia & 2 \\
UK & 12 & Austria & 1 \\
Canada & 11 & Croatia & 1 \\
Taiwan & 11 & Korea & 1 \\
South Africa & 8 & Malaysia & 1 \\
Germany & 9 & Norway & 1 \\
India & 8 & Russia & 1 \\
Israel & 6 & Singapore & 1 \\
New Zealand & 5 & Sri Lanka & 1 \\
Indonesia & 5 & Thailand & 1 \\
\hline
\end{tabular}

Table 8 Number of new coral reef species described by various authors: 1980-2014

\begin{tabular}{lcl}
\hline Author & Species & Areas of specialization \\
\hline J. Randall & 497 & Numerous families \\
G. Allen & 231 & Pomacentridae, Labridae and Gobiidae \\
R. Winterbottom & 89 & Gobiidae \\
R. Fricke & 66 & Callionymidae and Tripterygiidae \\
M. Erdmann & 63 & Deep reef species from 50+ m \\
W. Schwarzhans & 62 & Bythitidae \\
P. Møller & 60 & Bythitidae \\
A. Gill & 58 & Pseudochromidae and Xenisthmidae \\
D. Greenfield & 53 & Gobiidae \\
D. Hoese & 50 & Gobiioid fishes \\
T. Suzuki & 48 & Gobiidae \\
H. Larson & 41 & Gobiioid fishes \\
O. Gon & 32 & Apogonidae \\
R. Kuiter & 43 & Syngnathidae and Labridae \\
V. Springer & 36 & Blenniidae \\
W. Smith-Vaniz & 34 & Carangidae, Opistognathidae and \\
J. Williams & 31 & Blenniidae \\
\hline
\end{tabular}

reef species. This total amounts to $34.7 \%$ or roughly one of every three coral reef species described during those 34 years. Although these new discoveries include a wide range of families, the groups that have particularly attracted his attention include Labridae (110 species), Gobiidae (68 species), Serranidae (44 species), Apogonidae (46 species), and Pomacentridae (38 species). Jack Randall has 
Fig. 2 John E. Randall (left) and the author at the Sixth IndoPacific Fish Conference, Durban, South Africa, 2001

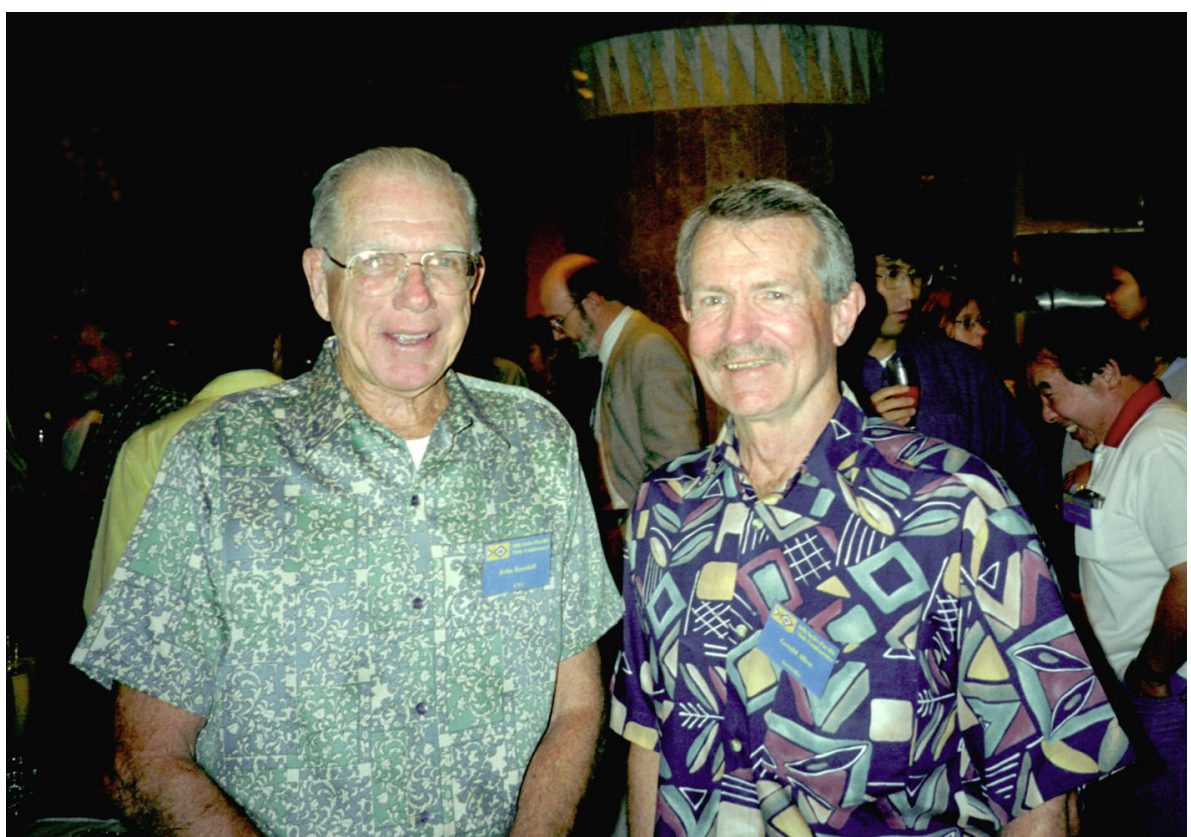

served as an inspiration to several generations of ichthyologists, having frequently offered encouragement (and authorship of joint papers) to a legion of young students. In recognition of his many achievements he was presented with the Bleeker Award at the Sixth Indo-Pacific Fish Conference at Taipei. I am indeed very fortunate to have the distinction of being Jack's first Ph.D. student at the University of Hawaii back in the 1960s.

\section{Field studies}

Field expeditions, large and small, continue to flourish and provide a seemingly endless supply of new discoveries. The use of scuba gear for reef fish collecting has become standard procedure over the past few decades. There has been a shift in recent years from large rotenone collections to more specialized methods in which certain rare or potentially new species are targeted, using spears, small barrier nets, and anaesthetics. In the latter category, quinaldine was formerly the chemical of choice, but due to its great expense and carcinogenic properties, it has largely been replaced with clove oil (Robertson and Smith-Vaniz 2010). Although rotenone remains a highly effective method of collection, particularly in remote, previously uncollected areas, it is very expensive, difficult to transport (now classified as a hazardous material), and its use is often discouraged by government authorities (Robertson and Smith-Vaniz 2008).

Field work is the prime ingredient for generating new species descriptions, and for this reason I have endeavoured to provide at least cursory information regarding the
Table 9 Summary of coral reef fish field work conducted from 1980 to 2014 by selected institutions (see text) showing number of field trips to various regions in the Indo-Pacific. PNG refers to Papua New Guinea

\begin{tabular}{lrlr}
\hline Pacific Ocean & & Indian Ocean \\
\hline Indonesia & 63 & W Indian Ocean & 22 \\
Australia & 36 & East Africa & 21 \\
Melanesian islands (non & 28 & Arabian Peninsula & 11 \\
$\quad$ PNG) & & & 6 \\
Micronesian islands & 22 & Andaman Sea & 4 \\
Papua New Guinea & 19 & Cocos-Keeling and & \\
& & Christmas Is. & 64 \\
Polynesian islands & 18 & Subtotal & 268 \\
S. China Sea to Japan & 18 & Grand Total & \\
Philippines & 15 & & \\
Subtotal & 219 & & \\
\hline
\end{tabular}

main focal areas and some of the more active institutions involved with coral reef fish collecting in the Indo-Pacific region. Although not intended as a comprehensive summary, I contacted a number of the leading institutions for tropical reef fish surveys to serve as a rough index of field activities, with the main goal being to gain a better understanding of the level of activity as well as the main focal areas for field research. The ten institutions involved in this analysis include the following: Australian Museum, Sydney (AMS); Bishop Museum, Honolulu (BPBM); California Academy of Sciences, San Francisco (CAS); Muséum national d'Histoire naturelle, Paris (MNHN); National Museum of Nature and Science, Tokyo (NSMT); Naturalis Biodiversity Center, Leiden (RMNH); Royal 
Ontario Museum, Toronto (ROM); South African Institute of Aquatic Biodiversity (SAIAB); United States National Museum of Natural History, Washington, DC (USNM); and the Western Australian Museum, Perth (WAM). During the 34-year period covered by the present study, a total of 283 field trips were undertaken by these institutions or an average of about eight trips per year. A summary of these trips according to geographic regions is indicated in Table 9. These results show that the western and central Pacific Ocean, which boasts the greatest reef area and includes the species-rich Coral Triangle, have been the leading focal areas for field research. Indonesia was and continues to be an extremely fertile hunting ground for new species.

Although the analysis included a representative sample, there are numerous other museums, field stations, and universities that maintain Indo-Pacific coral reef fish collections and organize field expeditions. For example, there is renewed focus on the Red Sea, an acknowledged area of high endemism, using the latest genetic techniques. The Interuniversity Institute for Marine Sciences (formerly Heinz Steinitz Marine Biological Laboratory) at Eilat, Israel managed by the Hebrew University of Jerusalem has long been a centre for field research in the region, and more recently the King Abdullah University of Science and Technology (KAUST) near Jeddah, Saudi Arabia has launched an ambitious coral reef field program, contributing to a much better understanding of the Red Sea coral fish community. Similarly, the IRD (formerly ORSTOM) has played an active role in promoting field research and resultant taxonomic studies throughout the tropical IndoPacific. Finally, field surveys by major conservation organizations, particularly Conservation International (CI) and The Nature Conservancy (TNC), have been especially productive for new reef fish discoveries over the past 15 years.

Acknowledgments I thank Keiichi Maatsura for inviting me to undertake this study. The original fish mapping study and GIS analysis, which provided the database for the present analysis, was funded by Conservation International (CI). Robert Waller, formerly employed by CI's GIS laboratory, designed and implemented the analytical programs. I am especially indebted to Mark Erdmann (CI), who provided funding that enabled me to revive the mapping program and to Paul Collins, who adapted the program to the QGIS format and greatly improved its efficiency. I am also indebted to William Eschmeyer, for his wonderful gift to systematic ichthyology, The Catalog of Fishes, and his continual efforts in keeping it up to date. Helen Randall provided a comprehensive bibliography of husband Jack's numerous publications and summary of his frequent field excursions. Mark Allen helped with organization and analysis of the Excel database and also provided Figure 1. Finally, I thank the following persons for providing useful information that was used in the field studies analysis (see this section above for full names of institutions): Philippe Bouchet (MNHN), Elaine Heemstra (SAIAB), Bert Hoeksema (RMNH), Mark McGrouther (AMS), Keiichi Matsuura (NSMT), Sue Morrison (WAM), Jeffrey Williams (USNM), and Richard Winterbottom (ROM).

Open Access This article is distributed under the terms of the Creative Commons Attribution License which permits any use, distribution, and reproduction in any medium, provided the original author(s) and the source are credited.

\section{References}

Allen GR (1991) Damselfishes of the world. Mergus Verlag, Melle Allen GR (2008) Conservation hotspots of biodiversity and endemism for Indo-Pacific coral reef fishes. Aquat Conserv 18:541-556

Allen GR, Erdmann MV (2012) Reef fishes of the East Indies. Volumes I-III. Tropical Reef Research, Perth

Allen GR, Steene RC, Orchard M (2007) Fishes of Christmas Island (second edition). Christmas Island Natural History Association, Christmas Island

Banner AH, Randall JE (1952) Preliminary report on marine biology study of Onotoa Atoll, Gilbert Islands. Atoll Res Bull 13:1-62

Cornic A (1987) Poissons de l'Ile Maurice. Editions de l'Océan Indien, Stanley, Rose-Hill, Ile Maurice

Eschmeyer WN (ed) (2014) Catalog of Fishes: genera, species, references. Electronic version. http://research.calacademy.org/ research/ichthyology/catalog/fishcatmain.asp. Accessed 1 April 2014

Eschmeyer WN, Fricke R, Fong JD, Polack DA (2010) Marine fish diversity: history of knowledge and discovery (Pisces). Zootaxa 2525:19-50

Johnson GD, Ida H, Sakaue J, Sado T, Asahida T, Miya M (2012) A 'living fossil' eel (Anguilliformes: Protanguillidae, fam. nov.) from an undersea cave in Palau. Proc R Soc Lond B Biol 279:934-943

Nelson JS (1994) Fishes of the world. Third edition. Wiley, New York

Parenti LR (1984) On the relationships of phallostethid fishes (Atherinomorpha), with notes on the anatomy of Phallostethus dunckeri Regan 1913. Am Mus Novit 2779:1-12

Patten JM, Ivantsoff W (1983) A new genus and species of atherinid fish, Dentatherina merceri from the western Pacific. Jpn J Ichthyol 29:329-339

Randall JE (1955) A revision of the surgeon fish genus Ctenochaetus, family Acanthuridae, with descriptions of five new species. Zoologica-NY 40 part 4 (15):149-166

Randall JE (1995) Coastal Fishes of Oman. Crawford House Publishing, Bathurst, NSW, University of Hawai'i Press, Honolulu

Robertson DR, Smith-Vaniz WF (2008) Rotenone: an essential but demonized tool for assessing marine fish diversity. Bioscience 58:165-170

Robertson DR, Smith-Vaniz WF (2010) Use of clove oil in collecting coral reef fishes for research. Mar Ecol Prog Ser 401:295-302

Sabaj Pérez MH (ed) (2010) Standard symbolic codes for institutional resource collections in herpetology and ichthyology: an online reference,version 1.5 (4 October 2010). Am Soc Ichthyol Herpetol, Washington DC. http://www.asih.org/. Accessed 4 October 2010 